\title{
Laporan Kasus: Diagnosa Sindrom Loeffler dan Nekatoriasis Duodenum Berdasarkan Endoskopi
}

\section{Case Report: Endoscopic Diagnosis of Loeffler's Syndrome and Duodenal Necatoriasis}

\author{
Yuni Rahmawati ${ }^{1}$, Syifa Mustika², Harijono Ahmad ${ }^{2}$ \\ ${ }^{1}$ Program Pendidikan Dokter Spesialis Fakultas Kedokteran Universitas Brawijaya Malang \\ ${ }^{2}$ Laboratorium IImu Penyakit Dalam Rumah Sakit Umum Dr. Saiful Anwar Malang
}

\begin{abstract}
ABSTRAK
Nekatoriasis adalah infeksi cacing tambang yang disebabkan oleh Necator americanus dan terdistribusi luas ke seluruh daerah di negara tropis dan subtropis. Larva migran cacing ini dapat menyebabkan gejala pneumonitis yang disebut sindrom Loeffler. Diagnosis ditegakkan berdasarkan adanya telur cacing dalam tinja, tetapi bisa juga tidak terdiagnosis terutama pada kasus infeksi yang ringan. Pada kasus ini pria, 60 tahun, suku Jawa, petani, dirawat di rumah sakit karena anemia gravis, sesak napas, melena selama 1 minggu. Foto polos dada menunjukkan infiltrat di paracardial kanan dan kiri. Laboratorium menunjukkan eosinofilia masif, kadar hemoglobin sangat rendah $(1,7 \mathrm{~g} / \mathrm{dL})$, hypochrom mikrositik, penurunan saturasi besi, penurunan kadar albumin. Analisa pada tinja tidak menunjukkan adanya infeksi parasit, hasil endoskopi menunjukkan ulkus gaster duodenum multipel, banyak cacing ditemukan pada duodenum, ukuran $1 \mathrm{~cm}$ dan teridentifikasi sebagai Necator americanus. Keluhan pasien membaik setelah transfusi darah dan pemberian pirantel pamoat selama 3 hari. Kasus ini menggambarkan adanya infeksi berat cacing tambang (Necator americanus) yang ditandai dengan gejala anemia berat, dispepsia, perdarahan saluran cerna bagian atas, disertai wheezing, rhonki dan infiltrat di area paracardia kanan dan kiri. Analisis tinja metode hapusan langsung menunjukkan tidak adanya infeksi parasit, namun pemeriksaan endoskopi menunjukkan ada banyak infestasi cacing Necator americanus pada duodenum. Hal tersebut mungkin disebabkan karena analisa sampel tinja terbatas pada metode hapusan langsung. Pasien diterapi berdasarkan klinis, temuan endoskopi, dan menunjukkan respon klinis yang baik.
\end{abstract}

Kata Kunci: Anemia, endoskopi, melena, Necator Americanus, sindrom Loeffler

\begin{abstract}
The Necatoriasis is an infection of soil transmitted helminths caused by Necator americanus (hookworm). Larva migrans itself can causes pneumonitis called Loeffler's syndrome. The diagnosis can be confirmed by the discovery of worm eggs in the feces, but it could be underdiagnosed because of light infection. We reported a 60-year old farmer Javanese male hospitalized due to anemia gravis, shortness of breath and melena since a week ago. Chest X-ray showed infiltrat on paracardial right and left side. Blood test showed marked eosinophilia, severely low hemoglobin level (1,7 g/dL), hypochrom microcytic, with decreasing of iron saturation, and albumin level. Fecal analysis showed no parasitic infection, endoscopy revealed multiple gaster and duodenal ulcer, and many wormsin duodenum, $1 \mathrm{~cm}$ in size that confirmed as Necator americanus. The patient's symptoms subsided after blood transfussion and 3-day course of pyrantel pamoat treatment. The patient represents a severe infection of hookworm with severe anemic symptoms, dyspepsia, gastrointestinal bleeding accompanied by wheezing, rhonki and infiltrat on paracardia lung right and left side. Direct smear fecal analysis showed no parasitic infection, but endoscopic revealed a lot of number Necator americanus in duodenum, that might be due to the limitation of direct smear methods. The therapy program was planned based on clinical, endoscopic findings and show good clinical response.
\end{abstract}

Keywords: Anemia, endoscopic, melena, Necator Americanus, Loeffler's syndrome

Jurnal Kedokteran Brawijaya, Vol. 28, No. 1, Februari 2014; Korespondensi: Yuni Rahmawati. Laboratorium Ilmu Penyakit Dalam Rumah Sakit Umum Dr. Saiful Anwar Malang, Jl. Jaksa Agung Suprapto No. 2 Malang Tel. (0341)341945 Email: yunirahmawati999@gmail.com 


\section{PENDAHULUAN}

Cacing tambang (hookworm) adalah salah satu parasit yang banyak menginfeksi manusia dan umumnya terdiagnosa melalui penemuan karakteristik klinis seperti eosinofilia pada pemeriksaan darah dan telur dengan bentuk yang spesifik pada pemeriksaan tinja secara mikroskopik (1). Necator Americanus merupakan salah satu jenis cacing tambang yang menginfeksi sekitar 576740 juta. Hospes adalah manusia, tersebar di daerah tropis, subtropik, terutama pada populasi miskin dan sanitasi buruk (2). Di Indonesia infeksi oleh Necator americanus lebih sering dijumpai dibandingkan infeksi oleh Ancylostoma duodenale (3). Liu et al melaporkan adanya 3 pasien dengan infestasi cacing tambang di duodenum yang tervisualisasi pada endoskopi di Taiwan antara tahun 1983 hingga 1993 (1). Penegakan diagnosis merupakan bagian penting dalam menetapkan pengelolaan yang tepat. Diagnosis pada umumnya ditegakkan berdasarkan adanya telur cacing dalam tinja, tetapi bisa juga tidak terdiagnosis terutama pada kasus infeksi yang ringan. Laporan kasus ini menggambarkan penggunaan endsokopi untuk menegakkan diagnosis infeksi Necator americanus dengan dugaan awal ulkus peptikum dengan anemia.

\section{KASUS}

Seorang pria, petani 60 th datang dengan keluhan berak hitam sejak 1 minggu yang lalu, konsistensi lunak seperti petis $1-2 \mathrm{x} /$ hari, volume $\pm 100 \mathrm{cc}$. Keluhan diikuti nyeri ulu hati sejak 1 minggu yang lalu, hilang timbul, tidak berkurang dengan makanan, mual dan muntah. Sesak napas dikeluhkan sejak 1 minggu sebelum masuk rumah sakit (SMRS) bila beraktivitas yang muncul perlahanlahan dengan keluhan lain kaki agak bengkak. Pasien juga mengeluhkan batuk tidak berdahak sejak 1 bulan SMRS. Pasien merasa lemah badan dan terlihat pucat sejak 1 bulan terakhir, semakin memberat sejak 1 minggu SMRS.

Hasil laboratorium awal didapatkan $\mathrm{Hb} 1,70 \mathrm{~g} / \mathrm{dL}, \mathrm{MCV}$ $63,2 \mathrm{fL} \mathrm{MCH} \mathrm{14,9} \mathrm{pg,} \mathrm{penurunan} \mathrm{serum} \mathrm{iron,} \mathrm{leukosit}$ $8,05 \times 10^{3} / \mu \mathrm{L}$, eosinofilia $2,2 \%$. Foto rontgent dada menunjukkan infiltrat pada parakardia kanan dan kiri (Gambar 1).

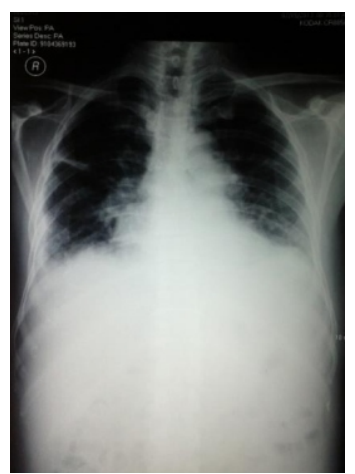

Gambar 1. Hasil foto polos dada (13 juli 2013) Keterangan: menunjukkan infiltrat pada paracardia kanan dan kiri

Pemeriksaan feces tes darah samar memberikan hasil positif, tetapi tidak ada telur cacing yang terdeteksi secara mikroskopik. Dengan dugaan awal sebagai penyakit ulkus peptikum dengan anemia, maka dilakukan endoskopi. Didapatkan adanya tukak multipel gastroduodenal dan infestasi cacing di duodenum dengan ukuran 0,5-1 cm (Gambar 2). Secara endoskopik tervisualisasi adanya penetrasi mukosa duodenum dan cacing yang bergerak aktif, yang kemudian teridentifikasi sebagai Necator americanus (Gambar 3).

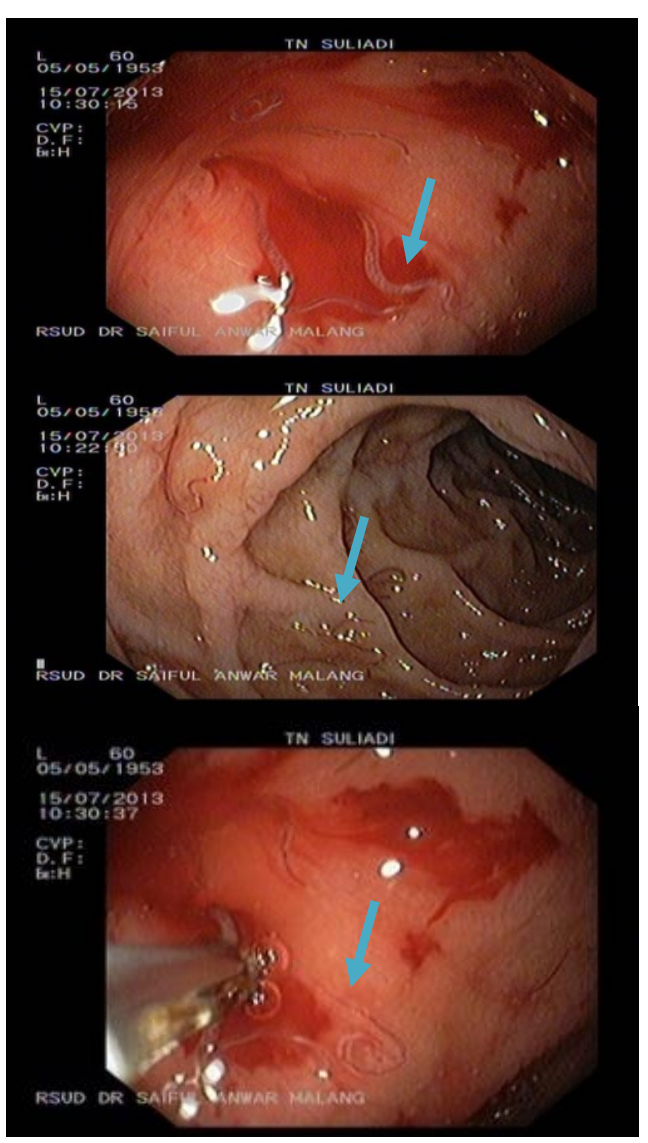

Gambar 2. Tukak multipel gastroduodenal dan infestasi cacing di duodenum pada pemeriksaan endoskopi

Keterangan: Tanda Panah menunjukkan adanya adanya tukak multipel gastroduodenal dan infestasi cacing di duodenum dengan ukuran 0,5-1 $\mathrm{cm}$

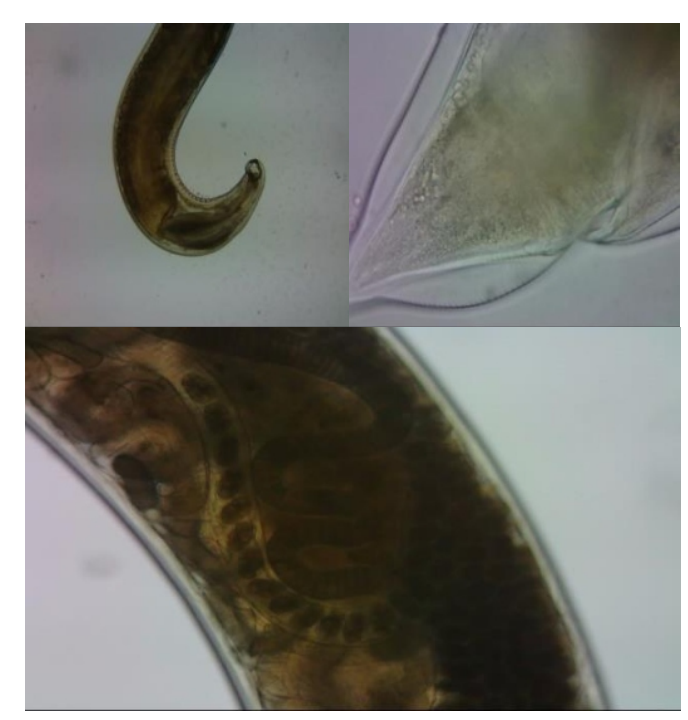

Gambar 3. Morfologi khas Necator americanus 
Pasien diberikan terapi transfusi PRC, pyrantel pamoat oral dan suplementasi zat besi oral. Satu minggu kemudian keluhan berkurang dan tidak ditemukan telur cacing di feces. Monitoring ulang akan dilakukan 2 minggu paska terapi dan selama fase observasi didapatkan peningkatan eosinofilia 7-16\%.

\section{DISKUSI}

Saat ini cacing tambang (hookworm) menginfeksi sekitar 576-740 juta orang di dunia, dimana 80 juta menderita infeksi berat. Tersebar di daerah tropis maupun subtropik, yaitu amerika, sub-sahara Afrika dan Asia, terutama pada populasi miskin dan sanitasi buruk. Infeksi parasit ini merupakan salah satu penyebab terjadinya perdarahan saluran cerna yang tersembunyi dan anemia. Jenis cacing tambang yang sering menginfeksi pada manusia adalah Ancylostoma dudenale dan Necator americanus yang dapat dibedakan berdasarkan morfologi kapsula mulut, bursae dan spikula. Necator hanya bisa ditransmisikan melalui penetrasi di kulit, dan manusia menjadi inang definitif (4).

Necator americanus menyebabkan kehilangan darah harian per cacing 0,01- 0,04 ml. Bentuk dewasa $n$. americanus dapat hidup selama tiga sampai lima tahun. $N$. americanus betina menghasilkan 5000-10.000 telur setiap hari. Telur cacing tambang berukuran $64-76 \mu \mathrm{m} x$ 36-40 $\mu \mathrm{m}$; berbentuk dengan shell hialin tipis sekitar 2-8 bersel embrio oval. (5)

Gejala klinis infeksi hookworm pada umumnya bersifat asimtomatik. Norman mendeskripsikan penyakit cacing tambang ini sebagai infeksi yang sangat berbahaya, oleh karena kerusakannya bersifat "silent and incidious"(3). Gejala umum yang terjadi saat terinfeksi yaitu rasa gatal di kulit kaki, dermatitis dan kadang-kadang ruam makulopapula sampai vesikel merupakan gejala pertama yang dihubungkan dengan invasi larva cacing tambang ini. Selama larva berada di dalam paru-paru dapat menyebabkan gejala batuk darah, wheezing, bronkitis, dan bronkopneumonia dapat terjadi ketika larva menerobos kapiler paru untuk memasuki ruang alveolar yang disebabkan oleh pecahnya kapiler-kapiler dalam alveoli paru-paru, dan perjalanan larva menuju trakhea (2). Sering ditemukan demam dan derajat eosinofilia yang tinggi (7-14\%). Hal tersebut bisa terjadi pada minggu ke 12 (6). Berat ringannya keadaan ini bergantung pada banyaknya jumlah larva cacing yang melakukan penetrasi ke dalam kulit. Rasa tak enak pada perut, kembung, sering mengeluarkan gas (flatus), diare, merupakan gejala iritasi cacing terhadap usus halus yang terjadi lebih kurang 2 minggu setelah larva mengadakan penetrasi ke dalam kulit (2). Puncak gejala pada umumnya terjadi 30-45 hari setelah infeksi dan menghilang secara perlahan, dan telur cacing bisa ditemukan sekitar 42 hari setelah infeksi (6).

Morbiditas pada penyakit cacing tambang sebagian besar disebabkan oleh kehilangan darah di saluran pencernaan, anemia defisiensi besi dan malnutrisi protein. Cacing dewasa di usus halus menyerap darah, merusak sel eritrosit, dan degradasi hemoglobin pada tubuh inang. Kehilangan darah dalam jangka lama bisa bermanifestasi sebagai pucat, lemah badan, sesak napas, anemia defisiensi besi, dan melena. Tes darah samar selalu positif di tinja pada infeksi cacing tambang (3). Anemia yang terjadi khas defisiensi besi, hipokrom, mikrositer. Kadar besi serum menurun tajam dan "total iron-binding capacity" (TIBC) meningkat, mengindikasikan cadangan zat besi yang sangat rendah. Anemia terjadi pada 10-20 minggu setelah infestasi cacing dan tergantung pada keadaan gizi pasien. Pada populasi dengan asupan zat besi yang tidak adekuat, sejumlah 40-160 cacing cukup untuk menyebabkan anemia. Akan tetapi jumlah cacing yang besar 500-1000 cacing bisa menyebabkan anemia yang signifikan walaupun dengan asupan zat besi yang cukup. Anak- anak yang menderita infeksi cacing tambang kronik akan mengalami gangguan pertumbuhan, intelektual dan fungsi kognitif (3).

Diagnosa dapat ditegakkan berdasarkan gambaran klinis seperti eosinofilia dan ditemukannya bentuk telur di analisa tinja. Kesalahan diagnosa bisa juga terjadi pada kasus tidak ditemukannya eosinofilia dan telur pada tinja (7-9). Pada infeksi ringan, diperlukan metode konsentrasi, seperti konsentrasi zinc sulphate, formol ether atau hapusan langsung Kato-Katz. Kelemahan pada pemeriksaan Kato-Katz adalah slide harus dibaca dalam 60 menit, karena telur tidak bisa dilihat dalam waktu lama. Tehnik ini merupakan tehnik perkiraan kuantitatif intensitas infeksi dengan menghitung jumlah telur per gram tinja. Sensitivitas pemeriksaan Kato-Kats meningkat dengan pemeriksaan sampel multipel berturut-turut (6).

Di sisi lain, endoskopi merupakan alat bantu diagnosis yang sangat penting pada penyakit saluran cerna, dan pernah dilaporkan juga beberapa kasus infeksi cacing tambang yang terdiagnosa melalui pemeriksaan endoskopi saluran cerna atas (10-14). Infeksi akut cacing tambang yang berat seringkali bermanifestasi berak warna hitam atau berdarah, sedangkan infestasi kronik seringkali berupa perdarahan yang tersembunyi. Setelah tahun 1970, jarang dilaporkan adanya penemuan endoskopi yang menunjukkan penetrasi cacing tambang pada mukosa duodenum dan pengambilan sampel spesies melalui biopsi forceps endoskopi (1). Pada kasus ini ditemukan adanya infestasi cacing pada duodenum dari pemeriksaan endoskopi, meskipun dari analisa tinja tidak ditemukan adanya telur cacing. Hal tersebut kemungkinan disebabkan oleh karena teknik analisa tinja terbatas pada metode hapusan langsung. Suatu penelitian menunjukkan metode hapusan langsung gagal mendeteksi telur cacing tambang sebesar $72,8 \%$, sedangkan metode sentrifugasi menunjukkan negatif palsu sebesar 0,97\% (15).

Pasien adalah seorang petani dengan kondisi ekonomi dan sanitasi lingkungan yang kurang, sehingga merupakan resiko tinggi untuk adanya infeksi cacing tambang. Kebersihan diri yang kurang, terutama kebiasaan defekasi dan sanitasi, status sosial-ekonomi rendah, kurangnya tingkat pendidikan merupakan faktor resiko terjadinya infeksi cacing tambang (16). Perbaikan sanitasi, kebersihan dan kemoterapi telah membuat infestasi cacing tambang jarang ditemukan pada negara maju, tapi masih menjadi infeksi endemik di dunia. Meskipun lebih jarang ditemukan daripada penyakit lainnya seperti tumor dan ulkus, infeksi parasit harus selalu dipertimbangkan sebagai diagnosa banding pada pasien dengan anemia defisiensi besi dan kehilangan darah melalui saluran cerna yang tidak bisa dijelaskan, terutama di daerah dengan sanitasi yang buruk. Oleh karena itu penting juga untuk mengamati distal duodenum secara hati-hati pada endoskopi saluran cerna atas meskipun secara klinis tidak dicurigai adanya infestasi cacing. Pada kasus ini juga didapati adanya infeksi cacing yang disertai sindrom Loeffler. Hal tersebut didukung dengan adanya manifestasi hipereosinofilia, ditemukan 
adanya infestasi cacing tambang di duodenum dan lesi di paru berupa infitrat, rhonki, dan wheezing.

Terapi antihelminthyang digunakan adalah golongan Benzimidazoles (BZAs), yaitu albendazole dan mebendazole. BZA membunuh cacing dewasa melalui ikatan dengan beta-tubulin dan selanjutnya menghambat polimerisasi mikrotubulus parasit (7). Pamoate levamisol dan pyrantel juga dapat digunakan. Studi meta-analisis menyebutkan efikasi terapi dosis tunggal pada infeksi cacing tambang adalah sebagai berikut: albendazole $72 \%$;

\section{DAFTAR PUSTAKA}

1. Kato T, Kamoi R, lida M, and Kihara T. Endoscopic Diagnosis of Hookworm Disease of the Duodenum. Journal of Clinical Gastroenterology. 1997; 24(2): 100102.

2. Pohan HT. Buku Ajar Ilmu Penyakit Dalam. Edisi 5. Jakarta: Interna Publishing; 1996.

3. Pineda N and Yang E. Hookworm: Ancylostoma duodenaleand Necator americanus. (Online) 2009. http://www.stanford.edu/group/parasites/ParaSites 2009/PinedaANDYang_Hookworm/PinedaANDYang_ Hookworm.htm [diakses tanggal 14 Juli 2013].

4. Hotez P, Bethony J, Bottazzi ME, Brooker S, and Buss P. Hookworm: "The Great Infection of Mankind". PLOS Medicine. 2005; 2(3): e67.

5. Vijayan VK. Tropical Parasitic Lung Diseases. The Indian Journal of Chest Diseases \& Allied Sciences. 2008; 50(1): 49-66.

6. Brooker S and Bundy D. Manson's Tropical Disease: Soil-transmitted Helminths (Geohelminths). Edisi 22. England:Saunders Elsevier; 2008; pp. 1515-1568.

7. McPhee $S$ and Papadakis MA. Current Medical Diagnosis and Treatment: Chemotherapy of Helminthic Infections. New York: Mc Graw Hill; 2008.

8. Prociv P and Luke RA. The Changing Epidemiology of Human Hookworm Infection in Australia. Medical Journal of Australia. 1995; 162(3): 150-154.

9. Yu SH, Jiang ZX, and Xu LQ. Infantile Hookworm Disease in China. A Review. Acta Tropica. 1995; 59(4): mebendazole 15\%; pyrantel pamoat 31\% (3).Pada kasus ini pasien mendapat terapi pyrantel pamoat selama 3 hari, transfusi darah dan pasien mengalami perbaikan klinis, laboratoris dan radiologis.

Pada kasus ini dilaporkan laki-laki berusia 60 tahun dengan sindrom Loeffler's, Necatoriasis duodenum disertai ulkus dan anemia berat. Dalam kasus ini prosedur endoskopi dapat bermanfaat dalam penegakan diagnosa, sehingga pasien bisa mendapatkan terapi yang sesuai dan mengalami perbaikan kondisi klinis.

265-70.

10. Dumont A, Seferian V, and Barbier P. Endoscopic Discovery and Capture of Necator Americanus in the Stomach. Endoscopy. 1983; 15(2): 65-66.

11. Genta RM and Woods KL. Endoscopic Diagnosis of Hookworm Infection. Gastrointestinal Endoscopy. 1991; 37: 476-478.

12. Bhargava DK, Dasarathy S, Chowdhry GC, Anand AC, and Saraswat V. Upper Gastrointestinal Bleeding Due to Hookworm (Ancyclostoma Duodenale)-A Case Report. Endoscopy. 1993; 25(8): 548-549.

13. Sharma BC, Bhasin DK, Bhatti HS, Das G, and Singh K. Gastrointestinal Bleeding Due to Worm Infestation, with Negative Upper Gastrointestinal Endoscopy Finding: Impact of Enteroscopy. Endoscopy. 2000; 32(4): 314-316.

14. Kuo YC, Chen PC, and Wu CS. Massive Intestinal Bleeding in an Adult with Hookworm Infection. Journal of Clinical Gastroenterology. 1995; 20(4): 348-350.

15. Dryden MW, Payne PA, Ridley RK, et al. Gastrointestinal Parasites the Practice Guide to Accurate Diagnosis and Treatment. Supplement to Compendium on Continuing Education. 2006;28(7A): 3-13.

16. Jiraanankul V, Aphijirawat W, Mungthin M, et al. Incidence and Risk Factors of Hookworm Infection in a Rural Community of Central Thailand. The American Journal of Tropical Medicine and Hygiene. 2011; 84(4): 594-598. 
